\title{
PRONUNCIATION IN EFL TEXTBOOKS USED IN SERBIAN SECONDARY SCHOOLS
}

In order to gain insight into the treatment of pronunciation in the EFL classroom, we analyzed 4 textbooks that are used at the fourth grade of secondary school in Serbia and belong to B2 and C1 levels according to Common European Framework of Reference (New Inside Out, English in Mind, New Matrix and New English File). The study aims to determine the number of pronunciation activities in the corpus, the pronunciation topics that receive the most attention and the nature of instructions provided in the exercises. The analysis shows that pronunciation does not occupy much space in EFL textbooks - the average percentage of pronunciation activities in the corpus is $7,13 \%$. Word stress, vowels and consonants are the components which have received the most attention. The textbooks do not possess specific instructions related to pronunciation, which is why the teacher's positive attitude towards the teaching of pronunciation is of great significance. Another possibility that teachers should consider is using the integrated approach to teaching, in which pronunciation would be taught along with other language skills.

Key words: pronunciation, English as a foreign language, textbooks, Serbian schools.

\section{INTRODUCTION}

Pronunciation represents an important aspect of learning a foreign language. Many people need effective communication skills for their job, e.g. for writing reports, presenting seminar papers, teaching English (Brazil, 1994: 1). Apart from this, pronunciation is vital to proper communication which can, but does not have to be job-related. Regardless of how often one uses English, they should dedicate attention to this component of English as well, primarily to achieve adequate mutual intelligibility (Derwing-Munro, 2005). 'Perfect pronunciation' which used to be set as a traditional goal is not likely to be achieved by the majority of learners and sometimes it can be 'devastating' (Morley, 1991: 498). Such a task

*azivanovic131313@gmail.com 
could be too demanding for learners, which could affect their motivation for reaching the goal. On the other hand, some occupations do require more than adequate intelligibility. As Morley (1991) claims, teachers of English should aspire to make their pronunciation similar to the pronunciation of native speakers.

A learner should master both segmental and suprasegmental features of a language in order to attain a desirable level of proficiency. The concept which plays an important role as regards segments' learning is functional load (King, 1967). The term refers to the contrast which two phonemes create in different contexts. For example, the phonemes $/ 1 /$ and $/ \mathrm{n} /$ have a higher functional load than the phonemes $/ \delta /$ and $/ \mathrm{d} /$ since the former more frequently occur in minimal pairs than the latter (Munro-Derwing, 2006: 522). For this reason, it is more important to understand the contrast between $/ 1 /$ and $/ \mathrm{n} /$ and the activities that deal with them should be incorporated in teaching to a greater extent. Intonation is one of the most important suprasegmental features. Wells (2006: 2) claims that it is usually neglected in teaching English as a foreign language. The author indicates that although there are many possible intonation patterns in English, their meanings differ. Thus, one should dedicate attention to this aspect of pronunciation as well so as to avoid misunderstanding in communication with native speakers of English.

Based on her empirical research into EIL $^{1}$ phonology, Jenkins (2002: 88) provides examples of situations in which inadequate pronunciation skills can lead to communication breakdown between non-native speakers of English. The most frequent errors can be classified into the following categories: consonant segments, tonic stress, vowel length and non-permissible simplification of consonant sequences. While describing a situation in which a Japanese learner mispronounced each word in the sentence, the author indicates that only the other Japanese students understood the speaker, while speakers whose L1 was not Japanese did not succeed even after four repetitions. Such examples demonstrate that incorrect pronunciation can bring about issues in interaction between non-native speakers of English as well.

There are many different ways in which one can acquire characteristics of English pronunciation. The authors who explored the pronunciation of Serbian learners considered the following possibilities: using British sitcoms for teaching pronunciation to primary school students (Klimenta, 2016), using Praat for teaching university students of English (Marković, 2017), introducing 'remedial exercises' which would address the pronunciation issues in the ESP classroom (Đurović-

\footnotetext{
${ }^{1}$ English as an international language.
} 
Silaški, 2013). Klimenta (2016) reports a positive impact of British sitcoms on pronunciation since the experimental group achieved significantly better results than the control group. The authors of the other two studies speak in favour of their methods based on their teaching experience. We think that all of these methods are useful; the ones which are used in teaching at the university level can also be incorporated into teaching at primary and secondary levels. Nevertheless, we believe that it is highly important that the textbook includes pronunciation exercises, which is why the teacher's first task should be choosing the appropriate textbook.

Levis and Sonsaat (2016: 111) suggest that pronunciation materials should be based on three general principles: "they should emphasize intelligibility, they should explicitly connect to other language skills, and they should provide sufficient and usable support for teachers". The first principle implies setting priorities for teaching. Different authors have different attitudes towards the importance of segmental and suprasegmental characteristics. Some of them believe that it is more significant to teach segments (Couper, 2006; Zielinski, 2006), while others point up the importance of suprasegmental features (Wennerstorm, 1999; Roach, 2002). The second principle suggests that pronunciation should be completely incorporated in the teaching of other skills. Even though it is sometimes necessary to teach pronunciation in a decontextualized way, this cannot be the only way since pronunciation represents an integral part of both speaking and listening (Levis-Sonsaat, 2016: 111). The third principle refers to the teacher's needs. In order to be able to impart their knowledge in the appropriate way, it is recommended that they use additional teaching materials.

The paper is structured in the following way: in Section 2, we present the research methodology, including the instrument, the research questions and the procedure. Section 3 includes the results obtained from the teaching materials analyzed in this paper. In Section 4, we discuss the most important results. The final section contains conclusions and suggestions for future research.

\section{METHODOLOGY}

\subsection{Instrument}

We have analyzed 4 textbooks that are used at the fourth grade of secondary school in Serbia: New Inside Out, English in Mind, New Matrix and New English File. The textbooks belong to $\mathrm{B} 2$ and $\mathrm{C} 1$ levels according to Common European Framework of Reference. We chose textbooks aimed at students at higher 
levels of proficiency because we had assumed that they would offer a wider range of topics for the analysis. The reason why we chose these textbooks specifically is quite simple. Namely, out of 15 textbooks that we examined (e.g. Solutions, New Headway, Real Life, etc.), these are the only ones that include pronunciation as one of the elements in each unit.

\subsection{Research questions}

The research questions that we attempt to answer in this paper are the following:

1) What is the number of pronunciation activities in the textbooks?

2) What pronunciation topics receive the most attention?

3) What is the nature of instructions provided in the exercises?

\subsection{Procedure}

The quantitative part of the analysis includes the calculation of activities that deal with pronunciation in each of the textbooks. We first calculated the number of all exercises in a given textbook, after which we determined the percentage of pronunciation activities. After that, we obtained these results for the entire corpus. In the next part of the analysis, we divided pronunciation into smaller topics occurring in the corpus (e.g. vowels, consonants, linking) and calculated the number of exercises dedicated to each topic. If two pronunciation elements were covered in one activity, e.g. consonants and vowels, we counted them as two activities. If an activity was divided into several parts, e.g. a), b), c), each part of the task was considered to be one activity. In addition, we wanted to discover whether the textbooks comprised pronunciation in units used for revision having in mind that these parts additionally emphasize the importance of previously introduced topics.

Furthermore, we also performed a qualitative analysis dealing with the nature of instructions provided in the activities. In this way, we intended to find out what types of activities were encouraged, if the instructions could be improved in some way and what would be the teacher's role concerning pronunciation teaching. 


\section{RESULTS}

In this section, we will present the analysis of pronunciation in each textbook. Special attention will be devoted to English phonemes and intonation. Table 1 provides the most frequently covered pronunciation topics in the textbooks; each topic is followed by the number of exercises in which it occurs.

Table 1: The most frequent pronunciation topics, followed by the number of exercises

\begin{tabular}{|c|c|c|c|c|}
\hline \multicolumn{5}{|c|}{ New Inside Out } \\
\hline $\begin{array}{l}\text { word stress } \\
\text { (10) }\end{array}$ & $\begin{array}{l}\text { intonation } \\
(6)\end{array}$ & weak forms (6) & $\begin{array}{c}\text { assimilation } \\
\text { (4) }\end{array}$ & silent letters (4) \\
\hline \multicolumn{5}{|c|}{ English in Mind } \\
\hline vowels (6) & $\begin{array}{l}\text { intonation } \\
(5)\end{array}$ & consonants (4) & linking (4) & word stress (3) \\
\hline \multicolumn{5}{|c|}{ New Matrix } \\
\hline weak forms (4) & vowels (3) & $\begin{array}{c}\text { sentence stress } \\
\text { (2) }\end{array}$ & word stress (2) & homophones (2) \\
\hline \multicolumn{5}{|c|}{ New English File } \\
\hline $\begin{array}{l}\text { word stress } \\
\text { (26) }\end{array}$ & vowels (23) & rhythm (18) & $\begin{array}{c}\text { consonants } \\
\text { (16) }\end{array}$ & $\begin{array}{c}\text { sentence stress } \\
\text { (10) }\end{array}$ \\
\hline
\end{tabular}

A total number of activities dealing with pronunciation in New Inside Out is 42, which constitutes $6.33 \%$ of all activities. As can be seen in Table 1, the authors place the most emphasis on word stress, which is addressed in 10 exercises. Intonation and weak forms are the topics of six activities. We can conclude that suprasegmental features occupy more space in this textbook; there is no exercise dealing with vowels or consonants. In all of the activities including intonation, the authors turn attention to the ways in which intonation can be used to express feelings such as rage, enthusiasm, reservation. Pronunciation exercises can be found in each of the twelve units except for the last one. New Inside Out includes pronunciation in revision units as well. The instructions occurring in the activities frequently encourage pair work. Another significant characteristic of the instructions is a large number of questions in the activities. In this way, the authors motivate learners to actively participate in class.

English in Mind deals with pronunciation in 27 out of 483 exercises, which makes up 5.59\%. The authors of this textbook do not give an advantage to any of pronunciation topics having in mind their distribution: vowels - 6 activities, intonation and consonants -5 activities each and linking -4 exercises. We can 
observe that the authors do not undermine the importance of segments, as is the case in New Inside Out. Learners have the opportunity to practise pronouncing the following vowels: /æ, e/, / I, i:/ and /ə/. Consonant pairs covered in English in Mind are $/ \theta, \mathrm{\partial} /$ and $/ \mathrm{n}, \mathrm{y} / .3$ activities comprise intonation in questions and 2 tasks deal with intonation in question tags. In the parts of the textbook dedicated to revision, which occur after every two units, only grammar and vocabulary exercises are included. The most frequent activity practised in this textbook is listening. In each unit there is at least one activity which requires repetition, based on which we can conclude that production is not neglected in this teaching material.

New Matrix has the lowest percent of pronunciation activities (16; 2.64\%). The highest number of pronunciation tasks deals with weak forms (4), which are followed by vowels (3). New Matrix does not include consonant segments. Furthermore, this is the only textbook which does not cover intonation in any exercise. In the three activities in which learners are supposed to identify words with the same sound, a large number of vowels is covered: /æ, p, o:, əu, $\wedge, \mathrm{i}:, \mathrm{v}, \mathrm{u}$ :, $\varepsilon$, ei, 3:/. There are no pronunciation exercises in revision units in New Matrix.

New English File possesses the largest number of tasks (688) and the largest number of pronunciation tasks $(89 ; 12.94 \%)$. Word stress is the most frequently occurring topic (26). It is followed by vowels (23), rhythm (18) and consonants (16). The activities comprise almost all vowel segments that exist in English - all 12 monophthongs and all diphthongs apart from / $\mathrm{i} /$. The activities enable mastering a high number of consonants as well: /d, g, h, d3, k, s, t, w, z, t , $\int, \theta$, ð/. Pronunciation is also revised in New English File. In this textbook, segments are presented in an interesting way. Namely, there is a picture accompanying every symbol which illustrates the use of this phoneme in a particular word. For instance, the consonant $/ \mathrm{k} /$ is followed by the picture of keys, the vowel / I/ is illustrated with the picture of fish, the diphthong /ai/ is represented by the picture of bicycle. Therefore, learners are exposed to somewhat different teaching materials, as well as the chance to connect the segments they learn with English vocabulary and learn the way they are transcribed using the International Phonetic Alphabet. New English File is the only textbook which stimulates learners to practise dictation.

\section{DISCUSSION}

Pronunciation activities make up $7.13 \%$ of the total number of activities in the corpus. The results obtained in this paper do not differ significantly from those 
analyzed by Derwing, Diepenbroek and Foote (2012), who used a much larger corpus in their research -48 ESL textbooks (12 series). The percentage of pronunciation exercises for each series varies from $0.4 \%$ to $15.1 \%(\mathrm{M}=5.0 \%)^{2}{ }^{2}$

In 2 of the 4 texts that we used as a corpus, there are no pronunciation tasks in revision units. Therefore, our results are similar to the above-mentioned study in this respect as well, since the authors found deliberate coverage of pronunciation in the review sections only in one of the five series. As indicated by Dickerson (2010), the most important aspects of pronunciation must be revisited so that students could have a more coherent picture (cited in Derwing-Diepenbroek, \& Foote, 2012: 33).

In each unit in English in Mind, pronunciation is only indicated by the title 'pronunciation' and the title of the topic, after which the learner is referred to one of the two pages in which all pronunciation activities are included; therefore, this aspect of language is separated from others. We do not find this decision appropriate since it may lead teachers to avoid dealing with pronunciation. It is possible that the authors believed that grouping all pronunciation activities in one place would facilitate learning English pronunciation. However, it is also possible to make an impression that pronunciation is less important than other elements which are covered in each unit. Similar observations were made by Marks (2006: 35): "all too often, pronunciation appears at the end of a unit, in the bottom righthand corner of a page, which only serves to reinforce its lowly status as the thing most likely to be omitted if time is short" (cited in Kanellou, 2011: 12).

The authors of the textbooks analyzed in this paper assign different degrees of importance to different pronunciation topics. For instance, intonation is the second most frequent element in English in Mind, while New Matrix does not deal with intonation in any activity. Such distribution could be related to different opinions about the relationship between segments and suprasegmentals mentioned in the introduction - whether the former or the latter should be more significant in teaching English pronunciation. Word stress, vowels and consonants are the most frequently covered topics in the corpus. More than half of the exercises are dedicated to these topics. Nevertheless, having in mind the coverage of other topics, we can conclude that suprasegmental features received more attention than segmental features.

The instructions occurring in the corpus which refer to the production of segments and suprasegmentals usually require repeating the material after listening.

2 The authors assessed pronunciation coverage by calculating a half-page for each pronunciation entry in comparison with the total number of pages in the textbook. 
It is possible that the authors think that going into details and the use of technical terms would be too demanding for the fourth grade of secondary school. However, having in mind that some activities contain additional explanations (most of them can be found in New English File), such as: "English vowel sounds are either short, long, or diphthongs (a combination of two short sounds)" (Oxenden-LathamKoenig, 2008: 23), we believe that more specific instructions related to articulation could also find place within the textbooks. For example, the task that indicates the distinction between /I/ and /i:/ could include the sentence: "The position of the tongue is higher during the pronunciation of the vowel /i:/." In this way, learners would find out that the difference between the two sounds does not only refer to their length, but also to the way these segments are articulated. Nevertheless, the explanations should not be too detailed. As suggested by Levis (1999: 41), the use of musical terms in teaching intonation, advocated by some authors (e.g. Chan, 1987), may include unnecessary details.

Bearing in mind that the textbook cannot contain all the information essential for mastering pronunciation elements, it is important to highlight the teacher's role. The results reported by Burns (2006), Kanellou (2011) and BurgessSpencer (2000) suggest that teachers need additional professional development as regards pronunciation teaching. We believe that this issue should be tackled both individually and collectively since the teacher's positive attitude towards pronunciation is crucial for creating a positive classroom atmosphere and effective pronunciation teaching.

\section{CONCLUSION}

Pronunciation's marginalized status has been indicated by many authors, e.g. it has been referred to as 'the EFL/ESL orphan' (Gilbert, 2010) or 'the Cinderella of language teaching' (Seidlhofer, 2001). Therefore, a small number of pronunciation activities in our corpus is not surprising. The reason for such treatment may be an opinion shared by many teachers of English - teaching pronunciation is not easy. It is possible that such an attitude leads authors to evade introducing pronunciation activities. Even though we do not claim that pronunciation is the most essential aspect of learning a foreign language and that it deserves more attention than grammar and vocabulary, for instance, we believe that it is of great significance for communication and that each English textbook should incorporate a certain number of pronunciation tasks. The possibility that teachers should also consider is teaching pronunciation along with other language skills. As Oxford (2001: 2) claims, the integrated-skill approach (within which the primary 
skills of listening, reading, speaking and writing are taught together with related skills such as pronunciation, syntax, etc.) leads to optimal ESL/EFL communication. The skills should not be taught separately since people normally use them in an integrated way when communicating with each other.

As regards the corpus analyzed in this paper, we can notice some inconsistencies, e.g. New Inside Out does not deal with segments in any of the exercises, New Matrix does not cover consonants or intonation, etc. We are of the opinion that both segmental and suprasegmental characteristics are equally important for pronunciation teaching; therefore, textbooks should contain both types of exercises. If some authors consider teaching segments to be more useful than teaching suprasegmentals, or vice versa, we believe that this should not affect the distribution of activities in such a way that one of the areas is omitted from the textbook. It is also important that pronunciation activities encourage active participation, i.e. students should practice pronunciation as much as possible. Based on the obtained results, we can conclude that the textbooks place more emphasis on perception than production.

Another topic related to pronunciation which we could deal with in future is the analysis of Serbian EFL teachers' attitudes - their relationship towards the importance of pronunciation, whether they analyze this aspect of language while choosing the textbook, how much time they dedicate to teaching pronunciation, etc. In such research, we could compare the attitudes of teachers from Serbia and other countries and thus shed more light on the place of pronunciation in Serbian schools.

Aleksandar Živanović

IZGOVOR U UDŽBENICIMA ENGLESKOG JEZIKA KOJI SE KORISTE U SRPSKIM SREDNJIM ŠKOLAMA

\section{Rezime}

Kako bismo dobili uvid u zastupljenost izgovora u nastavi engleskog jezika, analizirali smo 4 udžbenika koji se koriste u 4. razredu srednjih škola u Srbiji i pripadaju nivoima B2 i C1 prema Zajedničkom evropskom okviru za žive jezike (New Inside Out, English in Mind, New Matrix i New English File). Izabrali smo udžbenike namenjene učenicima koji poseduju više nivoe znanja jer smo pretpostavili da će takvi nastavni materijali ponuditi veći izbor tema za analizu. Rad nastoji da odredi broj aktivnosti koje se bave izgovorom u udžbenicima, teme koje su najzastupljenije, kao i prirodu instrukcija koje se nalaze u aktivnostima. Kvantitativni deo analize obuhvata računanje broja zadataka koji se bave izgovorom u korpusu, kao i procenat zastupljenosti svakog tipa zadatka (npr. vokali, 
konsonanti, intonacija). Kvalitativni deo analize ispituje prirodu instrukcija koje se mogu naći u vežbama. Analiza pokazuje da izgovor ne zauzima mnogo mesta u udžbenicima engleskog - prosečan procenat aktivnosti koje se bave ovom temom iznosi 7.13\%. Rezultati sugerišu da autori dodeljuju različit stepen važnosti različitim temama. Npr. intonacija je drugi najzastupljeniji element u udžbeniku English in Mind, dok se New Matrix ne bavi intonacijom ni u jednom zadatku. Akcenat, vokali i konsonanti su komponente koje su zadobile najviše pažnje u čitavom korpusu. Aktivnosti koje sadrže ove teme čine više od polovine svih vežbi. Udžbenici ne poseduju precizne instukcije koje se tiču izgovora, npr. kako bi učenik trebalo da upravlja govornim organima da bi proizveo određeni glas. Iz tog razloga, nastavnikov pozitivan stav prema podučavanju izgovora i želja za detaljnijim bavljenjem ovom veštinom dobijaju na važnosti. Mogućnost koju nastavnici treba da razmotre jeste integrativni pristup učenju, u okviru kog se izgovor podučava zajedno sa drugim jezičkim veštinama.

Ključne reči: izgovor, engleski jezik kao strani, udžbenici, škole u Srbiji.

\section{REFERENCES}

Brazil, D. (1994). Pronunciation for advanced learners of English student's book (Vol. 1). Cambridge: Cambridge University Press.

Burgess, J.-Spencer, S. (2000). Phonology and pronunciation in integrated language teaching and teacher education. System, 28(2), 191-215.

Burns, A. (2006). Integrating research and professional development on pronunciation teaching in a national adult ESL program. TESL Reporter, 39(2), 34-41.

Chan, M. (1987). Phrase by phrase: Pronunciation and listening in American English. Englewood Cliffs, NJ: Prentice Hall.

Couper, G. (2006). The short and long-term effects of pronunciation instruction. Prospect, 21_(1), 46-66.

Derwing, T. M.-Diepenbroek, L. G. \& Foote, J. A. (2012). How well do generalskills ESL textbooks address pronunciation?. TESL Canada Journal, 22-44.

Derwing, T. M.-Munro, M. J. (2005). Second language accent and pronunciation teaching: A research-based approach. TESOL quarterly, 39(3), 379-397.

Dickerson, W.B. (2010). Walking the walk: Integrating the story of English phonology. In: Levis, J.-LeVelle, K. (eds.) (2010). Proceedings from the 1st Conference of Pronunciation in Second Language Learning and Teaching. Ames, IA: Iowa State University. 10-23.

Đurović, T.-Silaški, N. (2013). An increase in imported goods, imports have increased - the role of teaching pronunciation in an ESP classroom. Romanian Journal of English Studies, 10(1), 89-98. 
Gilbert, J. (2010). Pronunciation as orphan: What can be done? SpeakOut: The newsletter of the IATEFL pronunciation special interest group, 43, 3-7.

Jenkins, J. (2002). A sociolinguistically based, empirically researched pronunciation syllabus for English as an international language. Applied linguistics, 23(1), 83-103.

Kanellou, V. (2011). The place and practice of pronunciation teaching in the context of the EFL classroom in Thessaloniki, Greece (Doctoral dissertation). Wales: Cardiff University.

King, R. D. (1967). Functional load and sound change. Language, 43, 831-852.

Klimenta, E. (2016). Uticaj britanskih humorističkih serija na izgovor engleskog jezika kod učenika osnovne škole (Doktorska disertacija). Novi Sad: Filozofski fakultet.

Levis, J. M. (1999). Intonation in theory and practice, revisited. TESOL quarterly, 33(1), 37-63.

Levis, J.-Sonsaat, S. (2016). Pronunciation materials. In: Azarnoosh, M.Zeraatpishe, M.- Faravani, A. \& Kargozari, H. R. (eds.) (2016). Issues in materials development. Rotterdam, The Netherlands: Sense. 109-120.

Marković, M. (2017). Information technologies in pronunciation teaching. In: Gudurić, S.- Radić Bojanić, B. (eds.) (2017). Languages and Cultures in Time and Space 6. Novi Sad: Faculty of Philosophy. 397-406.

Marks, J. (2006). Pronunciation in coursebooks again. SPEAK OUT!, 36, 33-36.

Morley, J. (1991). The pronunciation component in teaching English to speakers of other languages. TESOL quarterly, 25(3), 481-520.

Munro, M. J.-Derwing, T. M. (2006). The functional load principle in ESL pronunciation instruction: An exploratory study. System, 34(4), 520-531.

Oxford, R. (2001). Integrated skills in the ESL/EFL classroom. ERIC Digest, 6(1), 1-7.

Roach, P. (2002). English phonetics and phonology - A practical course. Cambridge: Cambridge University Press.

Seidlhofer, B. (2001). Pronunciation. In: Carter, R.-Nunan D. (eds.) (2001). The Cambridge Guide to Teaching English to Speakers of Other Languages. Cambridge: Cambridge University Press. 56-65.

Wells, J. C. (2006). English intonation: An introduction. Cambridge: Cambridge University Press.

Wennerstrom, A. (1999). Why suprasegmentals. TESOL Matters, 9(5), 20.

Zielinski, B. (2006). The intelligibility cocktail: An interaction between speaker and listener ingredients. Prospect, 21, 22-45. 


\section{TEXTBOOKS}

Gude, K.-Wildman, J. (2007). New matrix: Upper-intermediate. Student's book. Oxford: Oxford University Press.

Jones, C.-Bastow T. \& Jeffries, A. (2010). New inside out: Advanced. Student's book. Oxford: Macmillan Education.

Oxenden, C.-Latham-Koenig, C. (2008). New English file: Upper-intermediate. Student's book. Oxford: Oxford University Press.

Puchta, H.-Stranks J. \& Lewis-Jones, P. (2012). English in mind (2 ${ }^{\text {nd }}$ edition). Student's book 4. Cambridge: Cambridge University Press. 